\title{
OBCHODY 40-LECIA ŚMIERCI \\ DR. HAB. ROMUALDA GUSTAWA OFM (1911-1976), DYREKTORA BIBLIOTEKI UNIWERSYTECKIEJ KUL W LATACH 1950-1976
}

W dniu 14 stycznia 2016 r. minęła 40. rocznica śmierci wybitnego bibliotekarza i bibliografa, wielkiego miłośnika ksiąg, właściwego twórcy i wieloletniego dyrektora Biblioteki Uniwersyteckiej KUL, ojca Romualda Gustawa. Dla przypomnienia i uczczenia jego zasług, 29 lutego bieżącego roku odbyło się szereg poświęconych mu wydarzeń: konferencja, odsłonięcie pamiątkowej tablicy, otwarcie wystawy oraz wieczór wspomnień.

Główny bohater obchodów urodził się 5 stycznia 1911 r. w Zbarażu jako najmłodszy syn Jana Gustawa i Zofii z Szyngerów, na chrzcie świętym otrzymał imiona Michał Antoni. Jego powołanie dojrzało w trakcie nauki w Kolegium Serafickim w Radecznicy. W 1926 r. wstąpił do zakonu bernardynów w Leżajsku, przyjmując imię Romuald. Miłością do książek zapałał już w nowicjacie, powierzono mu bowiem opiekę nad klasztorną biblioteką. W czasie pobytu we Lwowie, gdzie uczył się najpierw w klasycznym Gimnazjum IV im. Jana Długosza, potem w bernardyńskim Studium Generale i na Wydziale Teologicznym Uniwersytetu Jana Kazimierza, także zajmował się pracą bibliotekarską. W 1936 roku uzyskał magisterium i przyjął święcenia kapłańskie. Skierowany przez władze zakonne do Krakowa pełnił tam różne funkcje, był również generalnym bibliotekarzem zakonu i archiwariuszem. W 1947 r. został wicepostulatorem procesów kanonizacyjnych bł. Jana z Dukli i Szymona z Lipnicy.

W 1946 r. podjął studia specjalistyczne na Wydziale Teologicznym Katolickiego Uniwersytetu Lubelskiego; od tej pory aż do śmierci związany był z tą Uczelnią. W 1947 r. uzyskał doktorat z teologii i został na krótko starszym asystentem przy I Katedrze Historii Kościoła, pełniąc jednocześnie obowiązki bibliotekarza w Bibliotece Wydziału Teologii.

W dniu 1 sierpnia $1950 \mathrm{r}$. Senat KUL mianował go dyrektorem Biblioteki Uniwersyteckiej KUL, która szybko stała się jego umiłowanym dziełem. Wydźwignął ją do rangi ośrodka o szerokim zakresie oddziaływania. Za jego kadencji ponad 
sześciokrotnie powiększyły się zbiory, szczególnie w zakresie czasopism zagranicznych, został rozbudowany i przebudowany budynek biblioteczny (oddano m.in. do użytku nową Czytelnię Główną, a także czytelnie: Informacji Naukowej i Bibliograficznej, Czasopism, Teologiczną, Rękopisów i Starych Druków), powiększył się personel i jego fachowość (dzięki licznym szkoleniom, wykładom, odczytom i kursom prowadzonym przez wybitnych bibliotekarzy i bibliotekoznawców z całego kraju).

O. Gustaw był wymagającym przełożonym, oczekującym od podwładnych, by kochali książki i angażowali się w pracę biblioteczną $\mathrm{w}$ stopniu jemu równym. Już na początku lat 50. XX w. wytyczył lubelskiej książnicy specjalne zadania w zakresie gromadzenia zbiorów i określił jej miejsce w krajowej sieci bibliotek naukowych. Od tej pory miała ona gromadzić w sposób szczególny piśmiennictwo religijno-teologiczne oraz obejmujące zagadnienia szeroko pojętej humanistyki.

Ze swoim promotorem ks. prof. Mieczysławem Żywczyńskim w latach 1948 i 1959 brał udział w organizowaniu transportów i przekazywaniu książek na rzecz KUL z tzw. Zbiornic Księgozbiorów Zabezpieczonych na Śląsku. W czasie kolejnych wyjazdów uzyskał wiele cennych starych druków i atlasów. Za jego dyrektorowania zbiory powiększały się także dzięki zakupom, darom i spuściznom prywatnych osób oraz wymianie zagranicznej i krajowej.

Wiele uwagi poświęcił dbałości o całość zbiorów kościelnych w Polsce. Organizował m.in. szkolenia dla archiwistów i bibliotekarzy bibliotek kościelnych z całej Polski. Był inicjatorem powstania Ośrodka Archiwa, Biblioteki i Muzea Kościelne (w 1957 r.) i członkiem komitetu redakcyjnego czasopisma „Archiwa, Biblioteki i Muzea Kościelne” oraz „Encyklopedii Katolickiej” (t. 1).

Nie zaniedbywał pracy naukowej. W 1965 roku uzyskał habilitację na Wydziale Nauk Teologicznych, przedkładając rozprawę Rozwój pojęcia historii Kościoła od I do XVIII wieku ${ }^{1}$. Ministerstwo Oświaty i Szkolnictwa Wyższego zatwierdziło ją dopiero w $1971 \mathrm{r}$. Był cenionym bibliografem i bibliotekoznawcą, jego zainteresowania naukowe koncentrowały się wokół problematyki bibliotekarskiej i archiwalnej, informacji bibliograficznej, metodologii pracy naukowej, historiografii kościelnej. Sporo uwagi poświęcił dziejom swego zakonu i hagiografii. Dziełem jego życia stała się dwutomowa Hagiografia polska, opublikowana w latach 1971-1972 2 . Był jej redaktorem, autorem przedmowy, bibliografii załącznikowej, życiorysu bł. Szymona z Lipnicy oraz uzupełniającego Aneksu.

W ostatnich latach życia odbył kilka podróży zagranicznych m.in. do Jugosławii, RFN, Austrii, Belgii, Holandii, Stanów Zjednoczonych i Kanady. Służyły one przede wszystkim wzbogaceniu jego doświadczeń zawodowych i nawiązaniu przydatnych kontaktów.

Zmarł nagle 14 stycznia 1976 r., w przeddzień swojego jubileuszu 25-lecia pracy na stanowisku dyrektora Biblioteki Uniwersyteckiej KUL. Został pochowany na cmentarzu przy ulicy Lipowej w Lublinie.

\footnotetext{
${ }^{1}$ R. Gustaw, Rozwój pojęcia historii Kościoła od I do XVIII wieku, Poznań 1965.

${ }^{2}$ Hagiografia polska. Stownik bio-bibliograficzny, red. R. Gustaw, t. 1-2, Poznań 1971-1972.
} 
Był postacią wybitną i charyzmatyczną, bez niego Biblioteka KUL nigdy nie zaistniałaby w obecnym kształcie, toteż 40. rocznica jego śmierci nie mogła przejść bez echa. Obchody rocznicowe zapoczątkowały obrady na temat Problemów nowoczesnej biblioteki naukowej. Tytuł konferencji nawiązywał do tematu spotkania jubileuszowego sprzed 40 lat, które nie doszło do skutku. Konferencja o tak samo brzmiącym tytule odbyła się wprawdzie w pierwszą rocznicę śmierci o. Gustawa (13-15 stycznia 1977 r.), zagadnienia związane z organizacją nowoczesnej biblioteki naukowej wymagają jednak aktualizacji. Intencją organizatorów było poszukiwanie odpowiedzi na pytanie czy dzisiaj problemy bibliotekarskie są podobne jak 40 lat temu, a zmieniły się jedynie narzędzia i formy, jakimi posługują się bibliotekarze czy też mamy do czynienia z zupełnie innymi zjawiskami i oczekiwaniami użytkowników a zawód bibliotekarza uległ diametralnej przemianie.

Obrady odbywały się w Czytelni Teologiczno-Filozoficznej Biblioteki Uniwersyteckiej KUL. Zgromadzonych gości i prelegentów powitała pani dyrektor mgr Barbara Zezula, starszy kustosz dyplomowany. Podkreśliła wagę tego dnia dla naszej instytucji. Swoje przemyślenia zaprezentowało ogółem 9 referentów, przedstawicieli środowisk akademickich Lublina, Krakowa, Wrocławia i Katowic.

W części pierwszej wystąpiły kolejno: mgr Urszula Poślada (kustosz dyplomowany, wicedyrektor Biblioteki Głównej Uniwersytetu Marii Curie-Skłodowskiej), mgr Ewa Matczuk (kustosz dyplomowany, kierownik Oddziału Informatyzacji Politechniki Lubelskiej), dr Anastazja Śniechowska-Karpińska (kustosz dyplomowany, zastępca dyrektora Biblioteki Głównej Uniwersytetu Medycznego w Lublinie) oraz dr Krystyna Michniewicz-Wanik (starszy kustosz dyplomowany, Biblioteka Wydziału Nauk Społecznych Uniwersytetu Wrocławskiego). $\mathrm{Na}$ początek mieliśmy okazję wysłuchać wypowiedzi dotyczącej zarządzania zbiorami tradycyjnymi i elektronicznymi w nowoczesnej bibliotece akademickiej. Była mowa o polityce racjonalnego gromadzenia materiałów bibliotecznych a także ich kosztów i promocji. Druga prelegentka podjęła temat funkcji edukacyjnej bibliotek uczelnianych, przedstawiając ofertę szkoleniową Biblioteki Politechniki Lubelskiej w zakresie kompetencji informacyjnych i omawiając usługi skierowane do różnego typu użytkowników.

Szczególne zainteresowanie uczestników konferencji wzbudziły zagadnienia związane z prawem autorskim, przedstawione przez dr Anastazję Śniechowską-Karpińską. Na przykładzie funkcjonowania Biblioteki Cyfrowej Uniwersytetu Medycznego próbowała ona przeanalizować sposoby wpływania kwestii prawno-autorskich na model udostępniania utworów w bibliotekach wirtualnych. Temat był na tyle interesujący, że w zasadzie zdominował dyskusję, jaka miała miejsce po wszystkich referatach.

Ostatnie wystąpienie poświęcone było transformacji bibliotek naukowych w obliczu zmieniających się potrzeb użytkowników. Za najbardziej istotną uznana została konieczność zapewnienia w nich odpowiednich narzędzi informacyjnych i przebudowy organizacyjnej.

Po przerwie kawowej głos zabrali kolejni prelegenci. Dr inż. Jolanta Szulc (Instytut Bibliotekoznawstwa i Informacji Naukowej Uniwersytetu Śląskiego 
w Katowicach) dokonała przeglądu literatury przedmiotu na temat systemu organizacji wiedzy w działalności bibliotecznej i informacyjnej, zebrany na podstawie poszukiwań w bazach danych: LISA (Library and Information Science Abstracts) i LISTA (Library, Information Science and Technology Abstracts). Wyodrębniła terminy wyszukiwawcze takie jak: folksonomie, klasyfikacja automatyczna, metadane, XML, ontologie, teoria klasyfikacji, teoria ogólna organizacji wiedzy. Zwróciła także uwagę na standardy metadanych wykorzystywane w katalogowaniu i prezentacji danych. Analizując zebrany materiał uznała, że w erze przed-internetowej koncentrowano się przede wszystkim na indeksowaniu i abstrahowaniu, obecnie natomiast dominujące stały się zagadnienia dotyczące katalogowania i klasyfikacji.

Mgr Ewa Dąbrowska z Biblioteki Jagiellońskiej w Krakowie przedstawiła zagadnienia organizacji Biblioteki Uniwersytetu Wileńskiego, której struktura opiera się na zadaniach a nie procesach bibliotecznych. Dysponuje ona nowoczesnymi rozwiązaniami i innowacyjnymi technologiami, jest otwarta na potrzeby czytelników, co wyraża się m.in. w całodobowej dostępności, wolnym dostępie do książek, rozbudowanym systemie komunikacji wewnętrznej i zewnętrznej, dobrze wyposażonych pracowniach komputerowych, salach pracy indywidualnej i grupowej, wreszcie strefach pracy i rekreacji, czyniących z biblioteki „trzecie miejsce".

Ostatnim prelegentem w tej części spotkania był ks. dr Jerzy Witczak (dyrektor Biblioteki Papieskiego Wydziału Teologicznego i Metropolitalnego Wyższego Seminarium Duchownego we Wrocławiu, przewodniczący Federacji Bibliotek Kościelnych FIDES), który ukazał dzieje komputeryzacji bibliotek kościelnych, wchodzących w skład Federacji Bibliotek Kościelnych FIDES. Na zakończenie słuchacze mogli się zapoznać z ofertą Wydawnictwa Naukowego PWN dotyczącą IBUK Libra, przedstawioną przez p. Piotra Kołacza.

Podstawowym wnioskiem wysnutym w czasie obrad było, że w XXI wieku realizacja podstawowych zadań bibliotecznych, takich jak gromadzenie, opracowywanie i udostępnianie materiałów bibliotecznych już użytkownikom nie wystarcza. Komputeryzacja i nowa organizacja wiedzy zmieniła znacząco wizerunek bibliotek naukowych. Obecnie muszą się one stać nowoczesnymi centrami informacyjnymi, które komunikują się z użytkownikami za pomocą nowoczesnych technologii i wychodzą naprzeciw ich oczekiwaniom. Duży nacisk powinien być położony na digitalizację zbiorów i ich udostępnianie w bibliotekach cyfrowych oraz repozytoriach.

Po przerwie kawowej nastąpił kulminacyjny punkt uroczystości. Jego Magnificencja Rektor Katolickiego Uniwersytetu Lubelskiego Jana Pawła II, ks. prof. dr hab. Antoni Dębiński, w obecności Prorektora ds. Nauki i Rozwoju dr. hab. Marcina Tkaczyka OFMConv, dokonał uroczystego odsłonięcia pamiątkowej tablicy poświęconej o. Romualdowi Gustawowi. W swoim przemówieniu zaznaczył, że wydarzenie to wprowadza nas w obchody 100 -lecia istnienia KUL i podkreślił jego wagę nie tylko dla Biblioteki, ale także dla całej społeczności akademickiej. Wyraził uznanie za wykonanie płaskorzeźby i wręczył pamiątkowy dyplom jej autorom - artystom Marii i Piotrowi Prusom. 
Zgromadzeni goście przeszli następnie do części wystawowej (na IV piętrze Biblioteki Uniwersyteckiej KUL przed Czytelnią Główną), aby obejrzeć ekspozycję , Całe życie wśród książek”. Pamięci Ojca Dyrektora Romualda Gustawa w 40. rocznice śmierci. Przygotowały ją mgr Jadwiga Jaźwierska i mgr Barbara Cech z Oddziału Zbiorów Specjalnych. Zamierzeniem autorek było ukazanie ojca Gustawa jako człowieka, naukowca, bibliotekarza, bibliografa, dyrektora, wreszcie także miłośnika ksiąg. Wystawa została podzielona na dwie części: pierwsza objęła materiały piśmiennicze (druki i rękopisy), druga - ikonograficzne (fotografie). Wśród eksponatów rękopiśmiennych znalazły się m.in. dokumenty i notatki dotyczące funkcjonowania biblioteki, organizacji kursów, powołania Ośrodka ABMK, fragmenty listów, wrażenia z podróży służbowych, zwłaszcza ostatniej do Stanów Zjednoczonych w 1975 roku. Na wystawie pokazane zostały także wszystkie drukowane publikacje o. Gustawa, artykuły i książki, w tym wydana habilitacja oraz Hagiografia polska. W ostatniej gablocie znalazły się wspomnienia i artykuły dotyczące jego osoby. Całość została bogato zilustrowana fotografiami, dokumentującymi 25-lecie dyrektorowania tego wielkiego bibliotekarza. Zgrupowano je tematycznie, według następującego klucza: Kursy $i$ wyklady, Wydarzenia w Bibliotece, $Z$ gośćmi Biblioteki, W pracy, Ojciec Dyrektor prywatnie. Na końcowej planszy zostało zamieszczone zdjęcie zrobione w listopadzie 1975 roku w czasie jego, ostatniej przed śmiercią, służbowej podróży do Stanów Zjednoczonych ${ }^{3}$.

Wystawę uroczyście otworzył Rektor KUL ks. prof. dr hab. Antoni Dębiński. Jej treść w kilku słowach przybliżyła jedna z autorek - Jadwiga Jaźwierska. Ekspozycja wzbudziła ogromne zainteresowanie gości, w pewien sposób przeniosła ich w lata sześćdziesiąte i siedemdziesiąte XX wieku, w ówczesną rzeczywistość Katolickiego Uniwersytetu Lubelskiego.

Po tych wzruszających momentach uczestnicy konferencji wrócili do sali obrad, gdzie zostały wygłoszone dwa referaty, przybliżające działalność o. Gustawa. Dyrektor Barbara Zezula przedstawiła go jako twórcę Biblioteki Uniwersyteckiej KUL w jej nowoczesnym kształcie, natomiast dr Artur Hamryszczak ukazał jego wkład w powstanie Ośrodka Archiwów Bibliotek i Muzeów Kościelnych. Podsumowania obrad dokonała dr Joanna Nastalska-Wiśnicka.

Tak zakończyła się oficjalna część uroczystości. Nie był to jednak koniec rocznicowych obchodów. Miłym ich akcentem był zaplanowany na późniejsze godziny wieczór wspomnień o ojcu Gustawie. Wzięli w nim udział emerytowani bibliotekarze i współpracownicy dawnego dyrektora, profesorowie, którzy go znali i cenili, a także współbracia z zakonu bernardynów z Krakowa.

Ostatnim punktem programu stała się msza św. za duszę śp. Romualda Gustawa, odprawiona 2 marca 2016 r. w kaplicy przy ul. Chopina 29 w Lublinie i złożenie wieńca na jego grobie, na cmentarzu przy ul. Lipowej.

Jego dzieło nie zostanie zapomniane, pozostanie w naszej pamięci jako ten, który ukochał książkę i bibliotekę ponad wszystko. Obecny w swojej podobiźnie na ścianie Czytelni Teologiczno-Filozoficznej, będzie patronował swemu dziełu na zawsze.

\footnotetext{
${ }^{3}$ Szczegółowo o wystawie zob. J. Jaźwierska, ,, Całe życie wśród książek”. Pamięci Ojca Romualda Gustawa w 40. rocznice śmierci. Wystawa w Bibliotece Uniwersyteckiej Katolickiego Uniwersytetu Lubelskiego, „Fides. Biuletyn Bibliotek Kościelnych”, 22 (2016) nr 2, s. 249-256.
} 


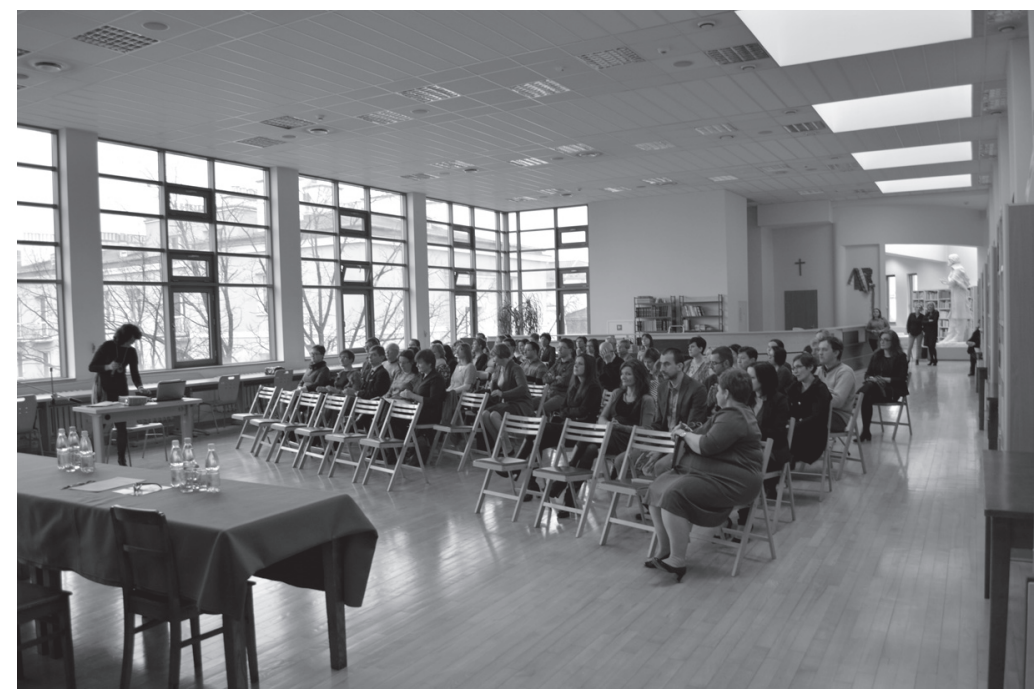

Fot. 1. Uczestnicy konferencji Problemy nowoczesnej biblioteki naukowej: konferencja w 40. rocznice śmierci dr hab. Romualda Gustawa OFM. Zbiory BU KUL.

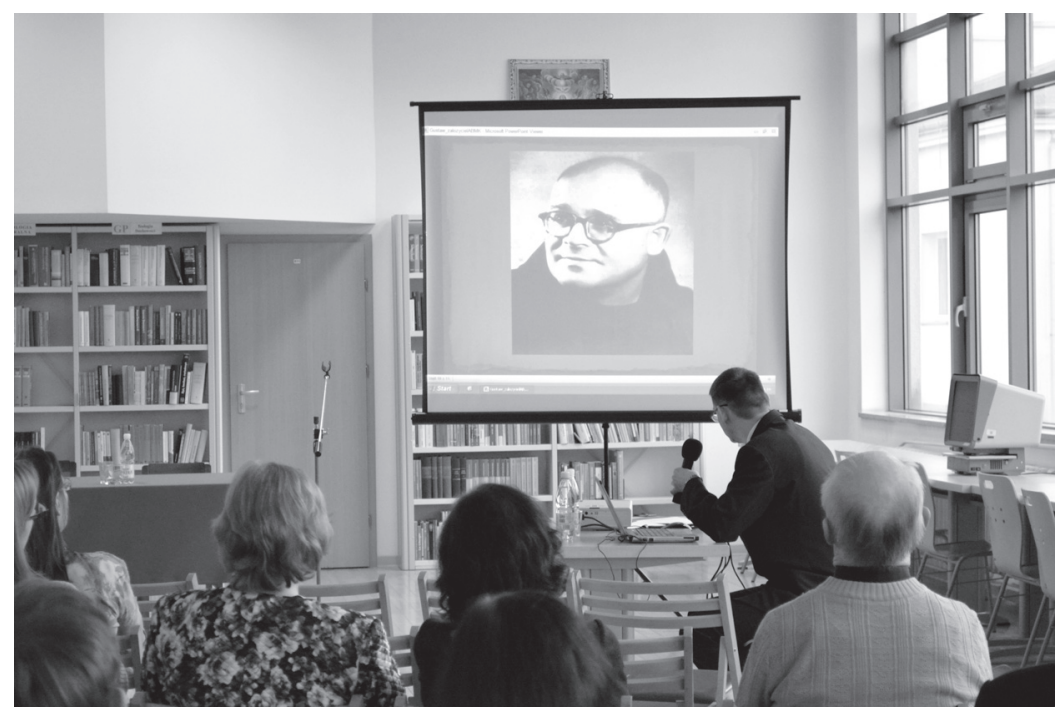

Fot. 2. Prezentacja referatu O. Romuald Gustaw OFM - założyciel Ośrodka Archiwów Bibliotek i Muzeów Kościelnych. Zbiory BU KUL. 


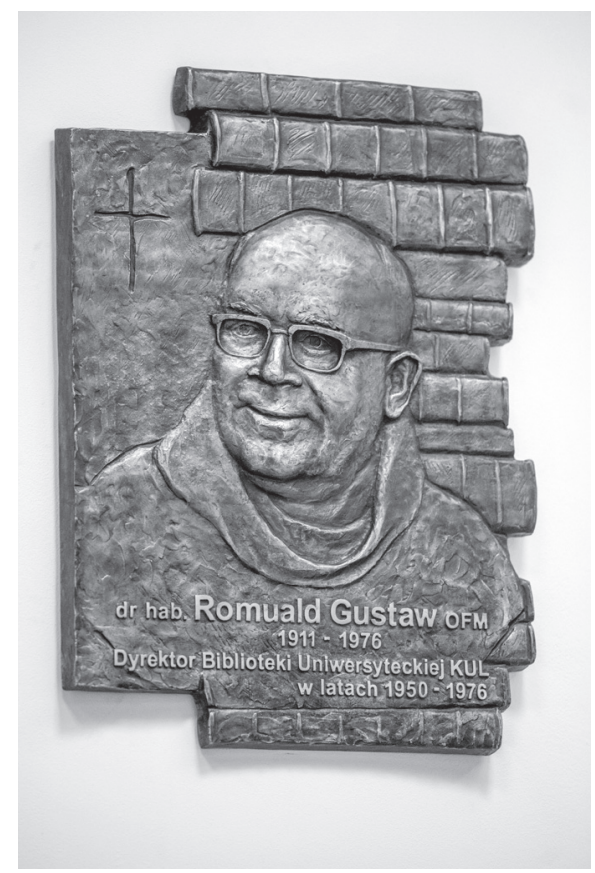

Fot. 3. Płaskorzeźba o. R. Gustawa, umieszczona w Czytelni Filozoficzno-Teologicznej BU KUL. Fot. Tomasz Koryszko.

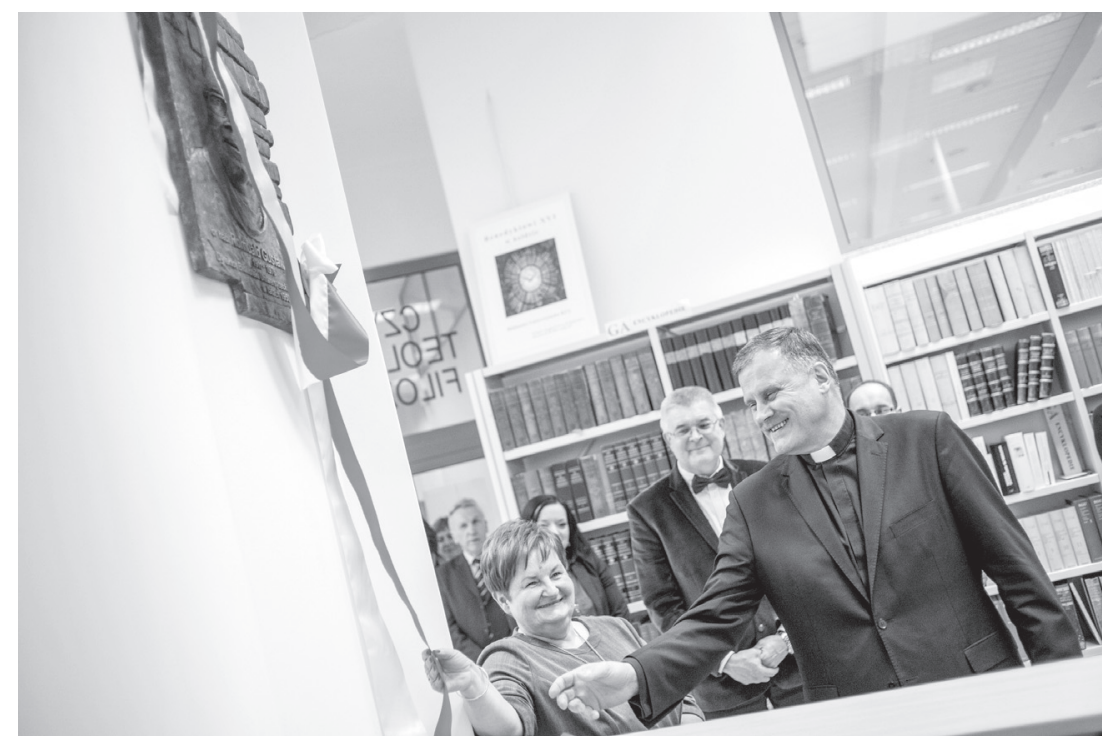

Fot. 4. Odłonięcie płaskorzeźby o. R. Gustawa przez Rektora KUL, ks. prof. Antoniego Dębińskiego i Dyrektor BUL mgr Barbarę Zezulę. Fot. Tomasz Koryszko. 


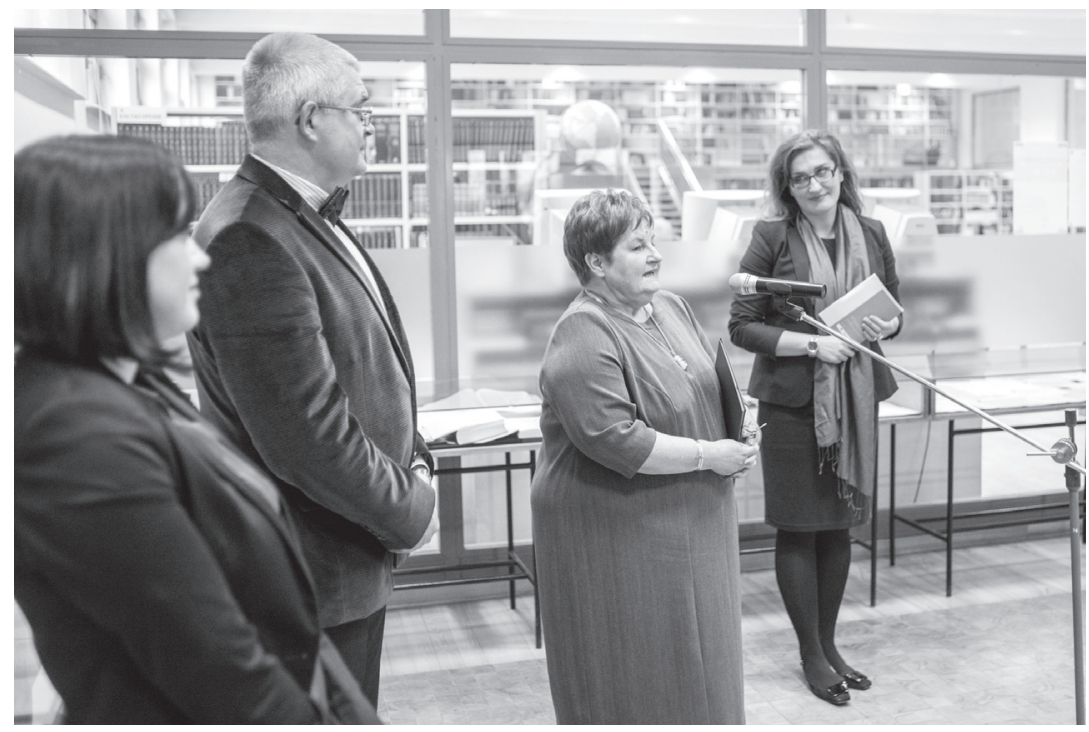

Fot. 5. Otwarcie wystawy „Całe życie wśród książek”. Pamięci Ojca Dyrektora Romualda Gustawa w 40. rocznicę śmierci. Przemawia Dyrektor BU KUL mgr Barbara Zezula. Z prawej strony jedna z autorek wystawy - mgr Jadwiga Jaźwierska. Fot. Tomasz Koryszko.

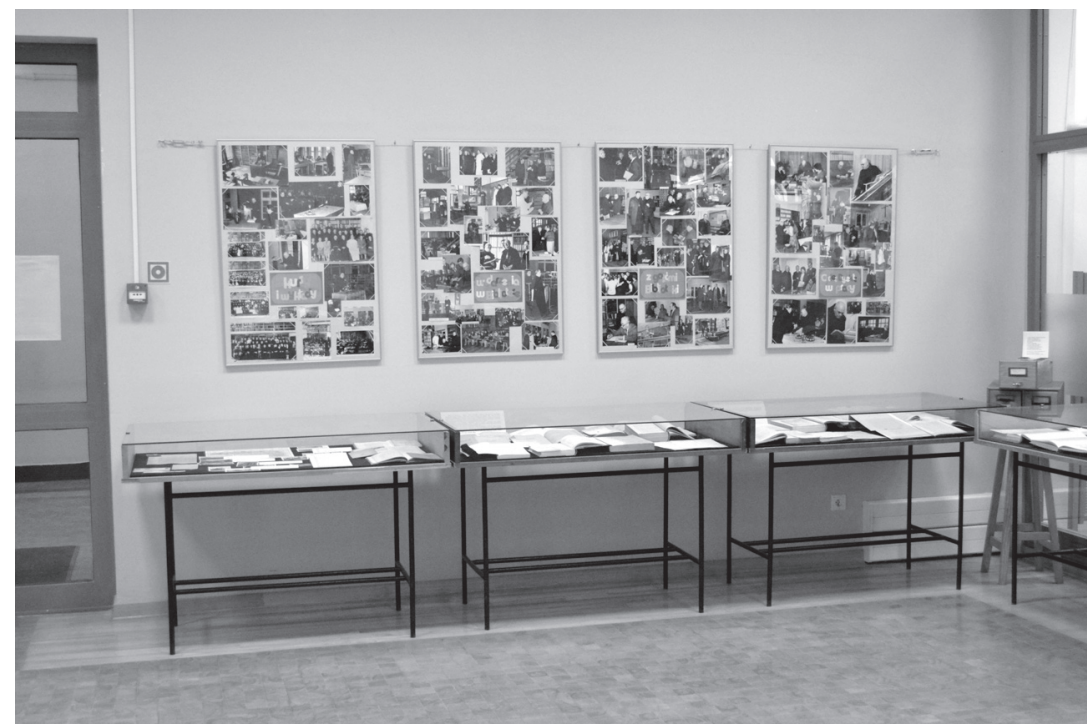

Fot. 6. Fragment wystawy „, Całe życie wśród książek”. Pamięci Ojca Dyrektora Romualda Gustawa w 40. rocznicę śmierci. Fot. Tomasz Koryszko. 


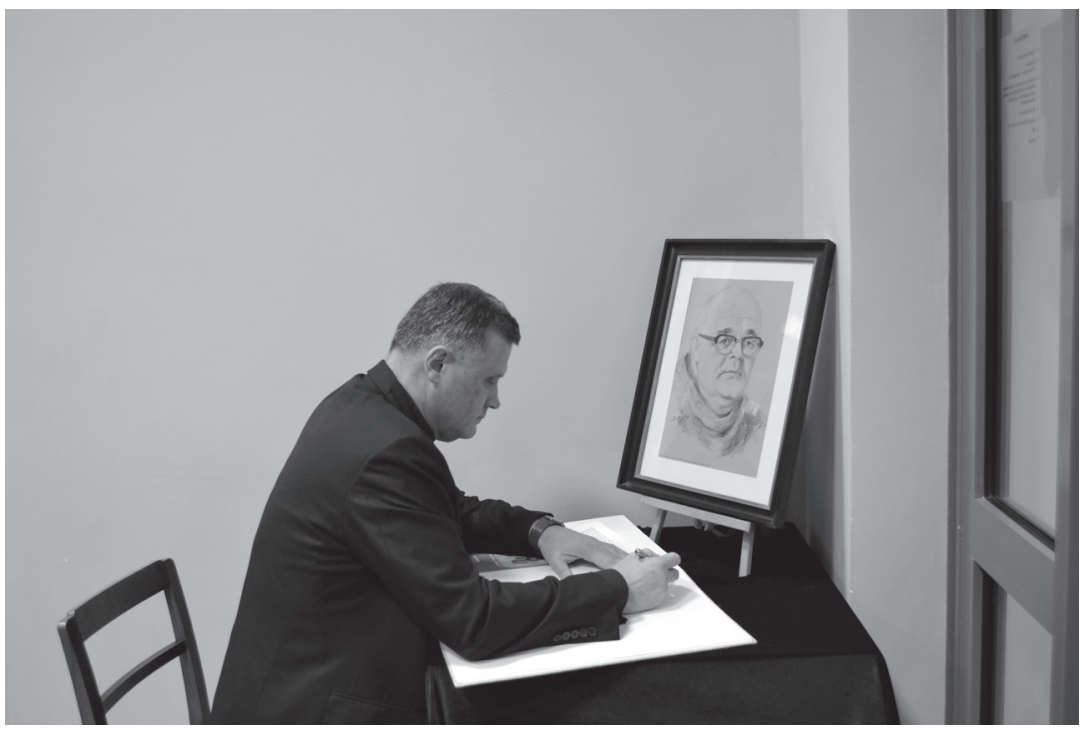

Fot. 7. Rektor KUL ks. prof. Antoni Dębiński wpisuje sie do księgi pamiątkowej wystawy. Fot. Tomasz Koryszko.

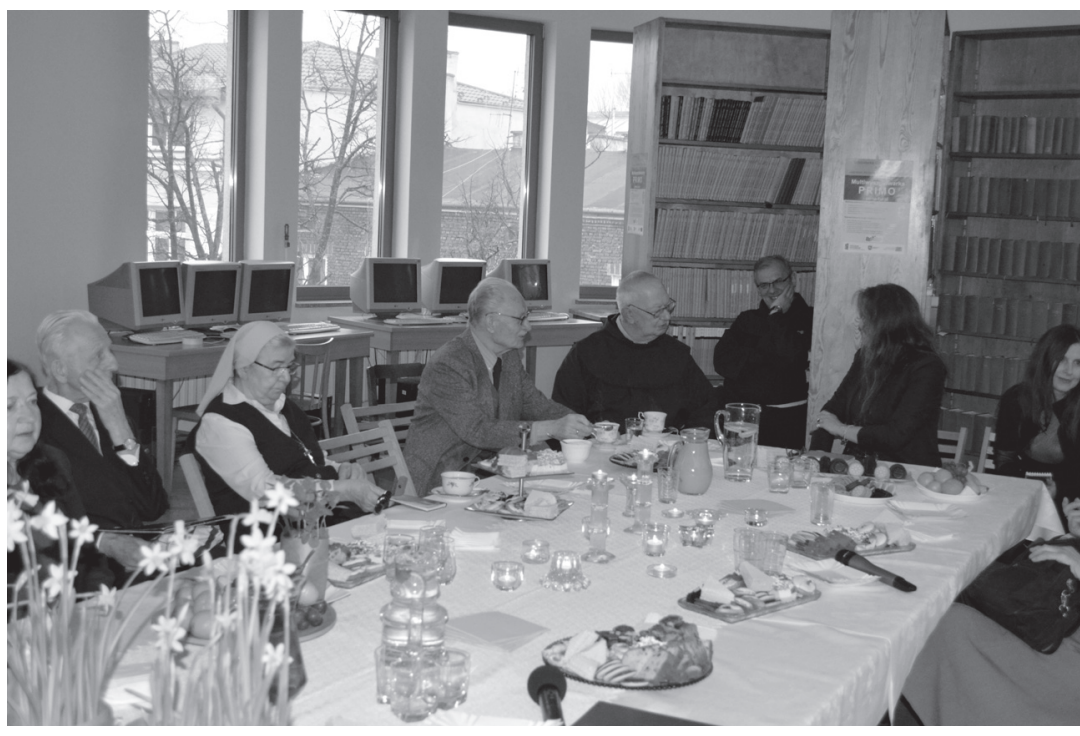

Fot. 8. Uczestnicy wieczornicy poświęconej pamięci o. R. Gustawa. Zbiory BU KUL. 


\section{Biblioteka Uniweryitecka RUL}

Oirodek frchiwôw, Bibliotek i Illuzeöw Koicielnych

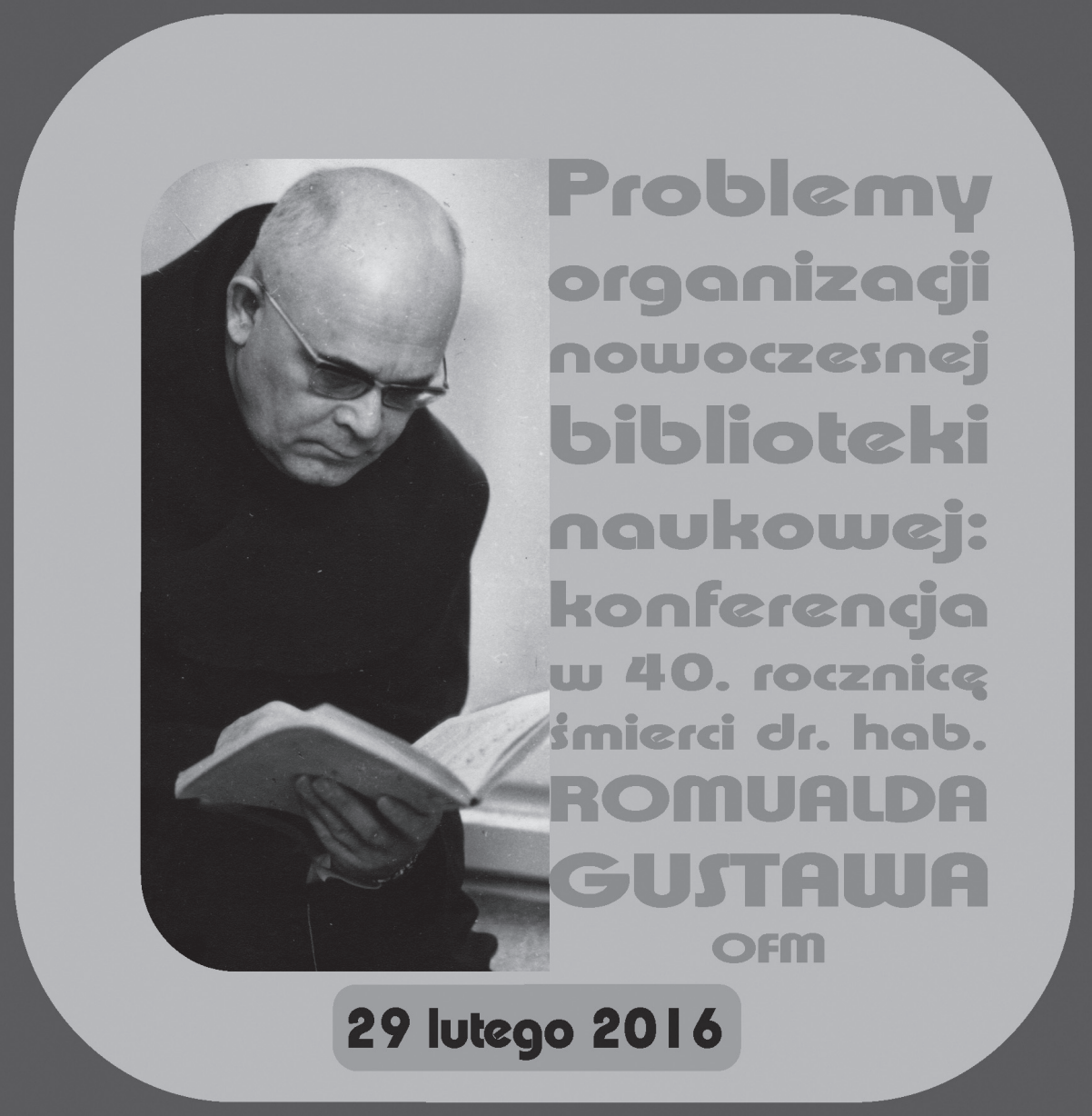

Biblioteka Uniweryytecka KUL

Lublin, ul. Chopina 27, Czytelnia Teologiezno-filozoficzna, IV pig̈tro

\section{这 Ceibå e}

Fot. 9. Plakat konferencji. Zbiory BU KUL. 